\title{
THE USE OF COURSE REVIEW HORRAY (CRH) STRATEGY TO PROMOTE STUDENTS' SELF- CONFIDENCE IN LEARNING VOCABULARY
}

\author{
Kamarudin ${ }^{\mathrm{a}}$, \\ IKIP Mataram, kamarudin.ntbe@gmail.com \\ Tawalib, \\ IKIP Mataram, \\ Muhammad Muhlisinc \\ IKIP Mataram,
}

\begin{abstract}
This research aims at finding out whether Course Review Horray strategy has effect toward students' self-confidence in learning vocabulary at the seventh grade students of MA NW Senyiur Keruak Lotim or not. This research was a quasi-experimental with two group pre-test and post-test design. The population was all the students of the seventh grade at MA NW Senyiur Keruak Lotim consisted of 74 students from 3 classes. The samples of this research were 2 classes consisted of 25 students each group. The experimental group was treated by using Course Review Horray strategy and control group was using Engage Study and Activate Strategy. The instruments of collecting the data were vocabulary test and questionnaire. After the data analysis completed, it was found that the questionnaire of students' percentage was $56 \%$ the students got qualification A as criteria Student master 90\%-100\% of all indicators, $24 \%$ students get qualification as B master $80 \%$ $89 \%$ of all indicators, $16 \%$ students get qualification as $\mathrm{C}$ master $65 \%-79 \%$ of all indicators, $4 \%$ students get qualification as D master 55\%-64\% and $0 \%$ students got qualification as $\mathrm{E}$ master $0 \%-54 \%$ of all indicators. The number of T-test score was (2.865) $>$ T-table (2.011). So, Course Review Horray (CRH) has effect towards students' self-condident in learning English vocabulary.
\end{abstract}

Keywords: Vocabulary, Students' Self-Confidence, CRH. 


\section{INTRODUCTION}

Mastering English cannot be separated part away of knowing its vocabulary items. Most of peoples tend to be able to speak English language prior to study the vacbulary items at first; hence it is the most crusial part of acquiring that language. Besides, self-confident also plays important role supporting the successfulness of acquiring English language, particularly speaking competence. Lauster (1992) reveals that self- confidence is an attitude or feeling confident in the ability of self so that the person concerned is not too anxious in his actions, feel free to do things and take responsibility for his actions, warm and polite in interacting with others, have encouragement to participate and get to know the advantages and vocabulary is the knowledge of meanings of words, and then vocabulary is the set of words for which the people know the meaning when the people speak or read orally.

One of the best ways to critically support that vocabulary items mastery will be enhanced is through Course Review Horray (CRH) strategy. It is believed to be the solution since Hamid (2014) reveals that Course Review Horray is teaching a fun strategy, since students are encouraged to play while learning to answer the questions that are presented attractively by teacher. Course Review Horray is learning strategy in the form of review, where the group with correct answer will say "Horray!" or another slogan.

Astuti (2011) Course Review Horay is also expected be able to examine students' understanding because after the teacher distributes the worksheet, the teacher will read the questions randomly at the time and then the questions are answered and discussed directly.

For this reason, This research aims at finding out whether Course Review Horray strategy has effect toward students' selfconfidence in learning vocabulary at the seventh grade students of MA NW Senyiur Keruak Lotim or not. 
Kamarudin et. al., The use of course...

\section{LITERATURE REVIEW \\ Theory of Vocabulary}

Vocabulary is the knowledge of meanings of words, and then vocabulary is the set of words for which we know the meaning when we speak or read orally (Kamil, \& Hiebert, 2005).

McCarten (2007) as cited in Oktaviani (2010) Stated that vocabulary is a challenge for learners, partly because of the size of the task, and partly because of the variety of vocabulary types to be learned including single words, phrases, collocations, and strategic vocabulary as well as grammatical patterning, idioms, and fixed expressions. The definition of vocabulary has been given by Hadfield (2008) as cited in Maryanti (2009) states vocabulary is a single word or two or three words that go together to make one meaning. According to Hiebert (2004) as cited in Fadli, (2009) Vocabulary is the knowledge of meaning of words which we can understand or recognize. Vocabulary of language in communication must be understood and recognize, because without understanding and recognizing the vocabulary of the target language, the verbal communication will not run well for the learner who are in this effort to master or understands the rules of vocabulary of the target language.

Learning vocabulary is component of language that maintains all of information about meaning and using word in language (Kridalaksana, 1993 in Fadli, 2009). Hackman (2008) as cited in Astuti (2011) states that vocabulary is more than a list of words, and although the size of one's vocabulary matters, it knows how to use it which matters most.

So based on the definitions above, it can be concluded that vocabulary is a stock of words in a language, written or spoken, with meaning that is considered as cultural meaning used by group or individual community.

\section{Types of Vocabulary}

Types of vocabulary, learning a language will mean nothing without learning its vocabulary. Herrel (2004) as cited in Rahmani (2015) states that there are different types of vocabulary:

a. Reading Vocabulary 
This refers to all the words an individual can recognize when reading a text.

b. Listening vocabulary

It refers to all the words an individual can recognize when listening to speech.

c. Writing Vocabulary

This includes all the words an individual can employ in writing.

d. Speaking vocabulary

This refers to all the words an individual can use in speech.

Harmer (1991) as cited in Rahmani (2015) claims that everyone has at least four basics of vocabularies they are as follows:

a. Speaking vocabulary. Some vocabularies which speak as the result of their listening process but only consist of view simple word.

b. Reading vocabulary. Types of vocabulary which allow people know and to use vocabulary little larger than the speaking vocabulary.

c. Writing vocabulary. This included the word in speaking vocabulary, plus other words that he can call up. This larger is much large than speaking and reading vocabulary.

d. Acquaintance vocabulary. It is the largest vocabulary. It includes the other three, but includes also, a considerable number of words which he owner have seen or heard before but does not know much about. He may remember enough about them so that he can usually guess their meaning in context.

In the other words, based on the above statements about the types of vocabularies, vocabularies have to be learning from the simple word to the difficult one. Starting from listening to the word, understanding it and speaking it, the learner will not be burden in learning a foreign language if the teacher often teaches the language from the simple level to the higher level.

\section{Indicators of Vocabulary}

Thornburry (2002) \& Brown (2003) state that, there are four indicators of vocabulary follow as:

a. Pronunciation 
Kamarudin et. al., The use of course...

Research shows that words that are difficult to pronounce are more difficult to learn. Potentially difficult words will typically be those that contain sounds that are unfamiliar to some groups of learners- such as regular and lorry for Japanese speakers. Many learners find that words with clusters of consonants, such as strength or crisps or breakfast, are also problematic.

b. Spelling

Sound-spelling mismatches are likely to be the cause of errors, either of pronunciation or of spelling, and can contribute to a words difficulty. While most English spelling is fairly law-abiding, there are also some glaring irregularities. Words that contain silent letters are particularly problematic: foreign, listen, headache, climbing, bored, and honest, cupboard, muscle, etc.

c. Meaning

When two words overlap in meaning, learners are likely to confuse them. Make and do are a case in point: you make breakfast and make an appointment, but you do the housework and do a questionnaire. Words with multiple meanings, such as since and still, can also be troublesome for learners. Having learned one meaning of the word, they may be reluctant to accept a second, totally different, meaning. Unfamiliar concepts may make a word difficult to learn. Thus, culture specific items such as word and expressions associated with the game cricket (a sticky wicket, a hat trick, a good innings) will seem fairly opaque to most learners and are unlikely to be easily learned.

d. Using word

The latter is the most authentic, but even that task is constrained by a contrived situation in which the test taker, usually in matter of seconds, has to come up with an appropriate sentence, which may or may not indicate that the test taker "knows" the word.

Based on the indicators above, the researcher will be focused on some indicators that commonly measure in vocabulary such as form, synonym, antonym, meaning and description.

\section{Assessing of Vocabulary}

Assessment is formative when teachers use it to check on the progress of their students, to see how far they have mastered 
what they should have learned, and then use this information to modify their future teaching plans, such assessment can also be the basic for feedback to the students (Madsen, 1983).

McCarten (2007) said that, Summative assessment is used at, say, the end of the term, semester, on year in order to measure what has been achieved both by groups and by individuals.

The purpose of vocabulary tests is to measure the comprehension and production of word used in speaking or writing, and in testing vocabulary; we also need to avoid presenting words in isolation, and then there are four general kinds of vocabulary test are presented (Madsen, 1983):

a. Limited responses, is for beginners there test items require either a simple physical action as "yes" or "no."

b. Multiple-choice completion is a test in which a sentence with a missing word is presented; students choose one of four vocabulary items given to complete the sentences.

c. Multiple-choice paraphrase, is a test in which a sentence with one word underlined is given, students choose which of four words is the closest in meaning to the underlined item.

d. Simple completion (words) has students write in the missing part of word that appear in sentences.

\section{Course Review Horray (CRH)}

Hamid (2014) Course Review Horray is teaching strategy is a fun strategy, since students are encouraged to play while learning to answer the questions that are presented attractively by teacher. Course Review Horay is learning strategy in the form of review. Where the group with correct answer will say Horay! or another slogan.

Astuti (2011) Course Review Horay is also expected be able to examine students' understanding because after the teacher distributes the worksheet, the teacher will read the questions randomly at the time and then the questions are answered and discussed directly.

This strategy is use Teacher-center-learning approach. In teacher-center- learning, students put all of their focus on the teacher. The teacher talks, while the students exclusively listen. 
Kamarudin et. al., The use of course...

During activities, students work alone, and collaboration is discouraged.

In Course Review Horay learning strategy there are some advantages and disadvantages of this strategy. The advantage of this study is the students interesting in learning vocabulary activity. The students learn more enjoy, and funny, so that's way the students not boring and stay focus to the teacher explanation that will make the students easy to receive material from the teacher. This activity will influence to the students vocabulary skill. Because they are train to speak in the enjoy situation from the strategy that the teacher use. Although this strategy is very fun, but there is some disadvantage of this strategy like, there is an opportunity for cheating.

\section{Self-Confident}

Lauster (1992) states that, self- confidence is an attitude or feeling confident in the ability of self so that the person concerned is not too anxious in his actions, feel free to do things and take responsibility for his actions, warm and polite in interacting with others, have encouragement to participate and get to know the advantages and disadvantages.

According to Brown (2003) states that, self-confidence is learners believe that they indeed are fully capable of accomplishing a task is at least partially a factor in their eventual success in attaining the task. In addition, Lauster (1992) explained that when individuals are more active, which aims to behave, eager to run day today life like the individual and the group are likely to have high self confidence.

The concept of self confidence is fundamentally a confidence to live your life, consider options and make decisions on their own to him that he was able to do something. According Sarastika (2014) self confidence is convincing in ability and judgment ourselves in doing the task and chooses effective approach. To develop confidence, there some aspects: To believe in his own abilities, dare to express their opinions, having a positive self concept, act independent in staking decisions, rational and realistic that to analysis of a problem. 


\section{RESEARCH METHOD}

This research was experimental research. Experimental research is characterized by much greater control over the research environment and in this case some variables are manipulated to observe their effect on other variables (Kothari, 2004 \& Miller, 2005).

The research of the study is quasi experimental with nonequivalent control group design by using pre-test and post-test design. In this research, the researcher gave different treatments for two groups. The group which was treated by using Course Review Horray Strategy is named experimental group and control group was treated by using Engage Study and Activate Strategy.

Population

This study was held in MA NW Senyiur Keruak Lotim consisted of of three classes; those are VII.A 25 students, VII.B 24 students, and VII.C 25 students. Thus, the total number of population was 74 students.

\section{Sample}

Of the population calculated, then there were only classes VII.A consist of 25 students as experimental group and class VII.C consist of 25 students as control group taken as the sample of the study. Thus, the total of the sample was 50 students.

\section{Research Instrument}

There were two instruments used; those were vocabulary test consisted of 25 questions in the form of multiple choices, and questionnaire consisted of 25 questions as well.

\section{Data Collection Technique}

To collect the data, it was used pre-test and post-test for both experimental calss and control class.

Pre-test was intended to know the prior knowledge of the students regarding the topics being researched and Post-test was given to know the students' capacity or capability regarding the topics being researched as well. 
Kamarudin et. al., The use of course...

\section{Data Analysis}

The data was analyzed through some steps such as descriptive statistics;

1. Mean score

$\bar{X}_{1}=\frac{\sum X_{1}}{N_{1}}$

2. Median

$M e=L+i\left(\frac{\frac{n}{2}-c f b}{f w}\right)$

3. Mode

$M o=L+i\left(\frac{f i}{f i+f 2}\right)$

4. Standard Deviation

$\mathrm{SD}_{\mathrm{D}} \sqrt{\frac{\sum D^{2}}{N}-\left(\frac{\sum D}{N}\right)^{2}}$

5. Inferential Statistics

$$
T=\frac{M x-M y}{\sqrt{\left(\frac{\sum x^{2}+\sum y^{2}}{N x+N y}\right)\left(\frac{1}{N x}+\frac{1}{N y}\right)}}
$$

(Arikunto 2006: 311)

6. Analizing data of the self confidence.

The questionnaire will be assed by using likert scale; this likert scale will have five options. They are very agree $=5$, agree $=4$, doesn't know $=3$, disagree $=2$, and very disagree $=1$.

The score of students' self-confidence was calculated by using this formula:

$\mathrm{NP}=\mathrm{R} / \mathrm{SM} \times 100$

Where:

$\mathrm{NP}=$ Score

$\mathrm{R}=$ The number of score

$\mathrm{SM}=$ The maximum score

Score interpretation criteria:

$0 \%-54 \% \quad:$ Very bad

$55 \%-64 \%$ : Bed

$65 \%-79 \% \quad:$ Enough 
$80 \%-89 \% \quad:$ Good

90\% - 100\% : Very Good

(Purwanto, 2010: 102 in Maiyanah 2015: 41).

\section{FINDINGS AND DISCUSSION}

\section{Data Description of Experimental Group}

The result of data analysis showed that the highest score was 88 and the lowest score was 60 . The mean score was 74.24 , the mode was 77.5, median was 77 range was 28 , and standard deviation was 10.70. Then, score experimental group, frequency distribution, histogram and polygon of the data and were also presented.

Chart 01: Histogram and Polygon of Experimental Group for Post-Test

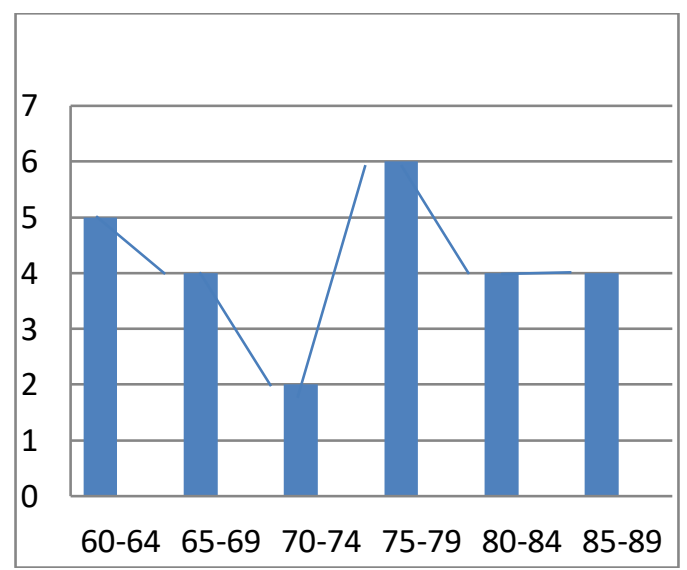

\section{Data Description of Control Group}

The result of data analysis showed that the highest score was 76 and the lowest score was 60 . The mean score was 66.68 the mode was 64.5 median was 60.84 range was 16, and standard deviation was 6.08. Then, score control group, frequency distribution, histogram and polygon of the data were also presented:

Chart 02: Histogram and Polygon of Control Group for Post-Test. 
Kamarudin et. al., The use of course...

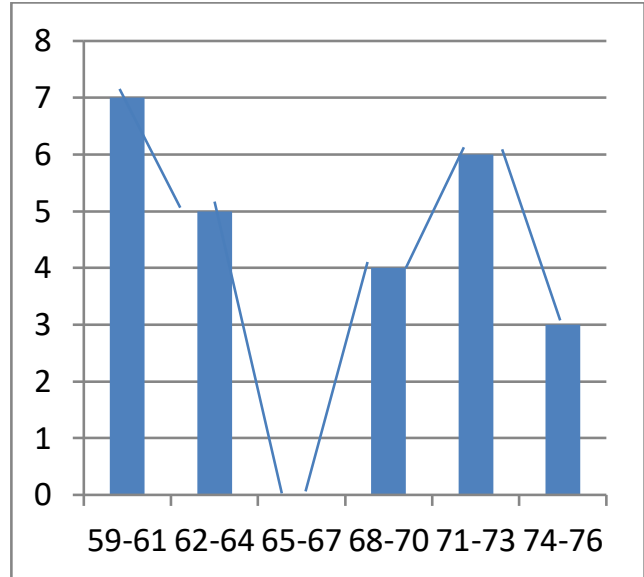

\section{Testing Hypothesis}

The hypothesis was tested by using t-test formula. To find out the result of $t$ test whether or not was higher from $t$ table ( $t$ test value $\geq \mathrm{t}$ table) was used by detemining the level of significance as well as the degree of freedom of samples minus two.

In this research, the sample of data was 25 students for experimental group and 25 students for control group; the total sample for both of groups was 50 , so the degree of freedom that was used $50-2=48$. Based on the t- test computation, it was found that $\mathrm{t}$-test $=2.865 \geq \mathrm{t}$-table $=2.011$.

\section{Students' Self-Confidence}

The number of questionnaire consists of 20 statements for experimental group. The questionnaires are consisting of 5 optional answer; very agree (1) agree (2) doesn't know, (3) disagree (4) and very disagree (5).

Scoring Qualification of Self-Confidence

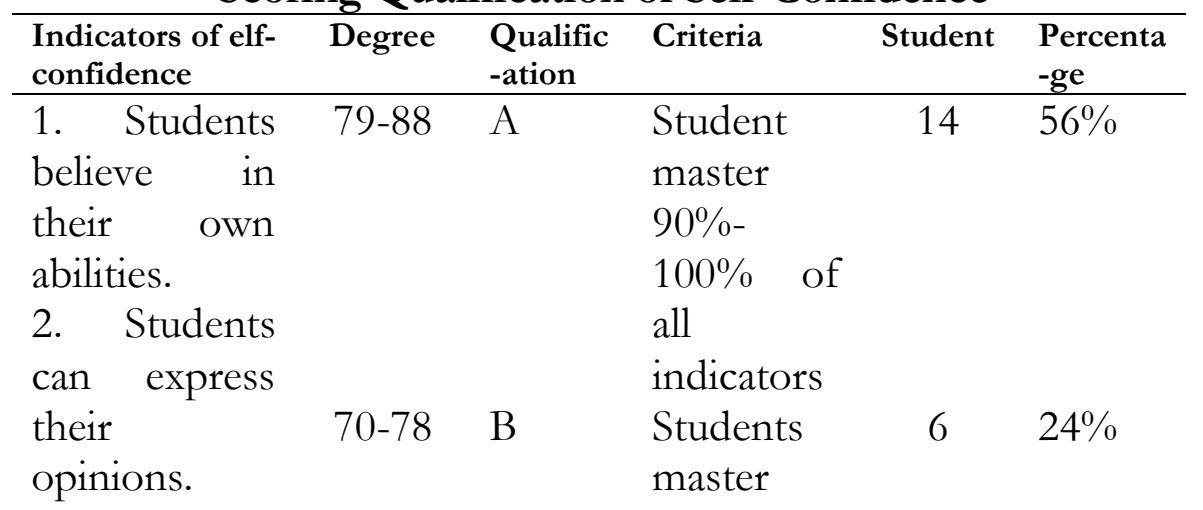




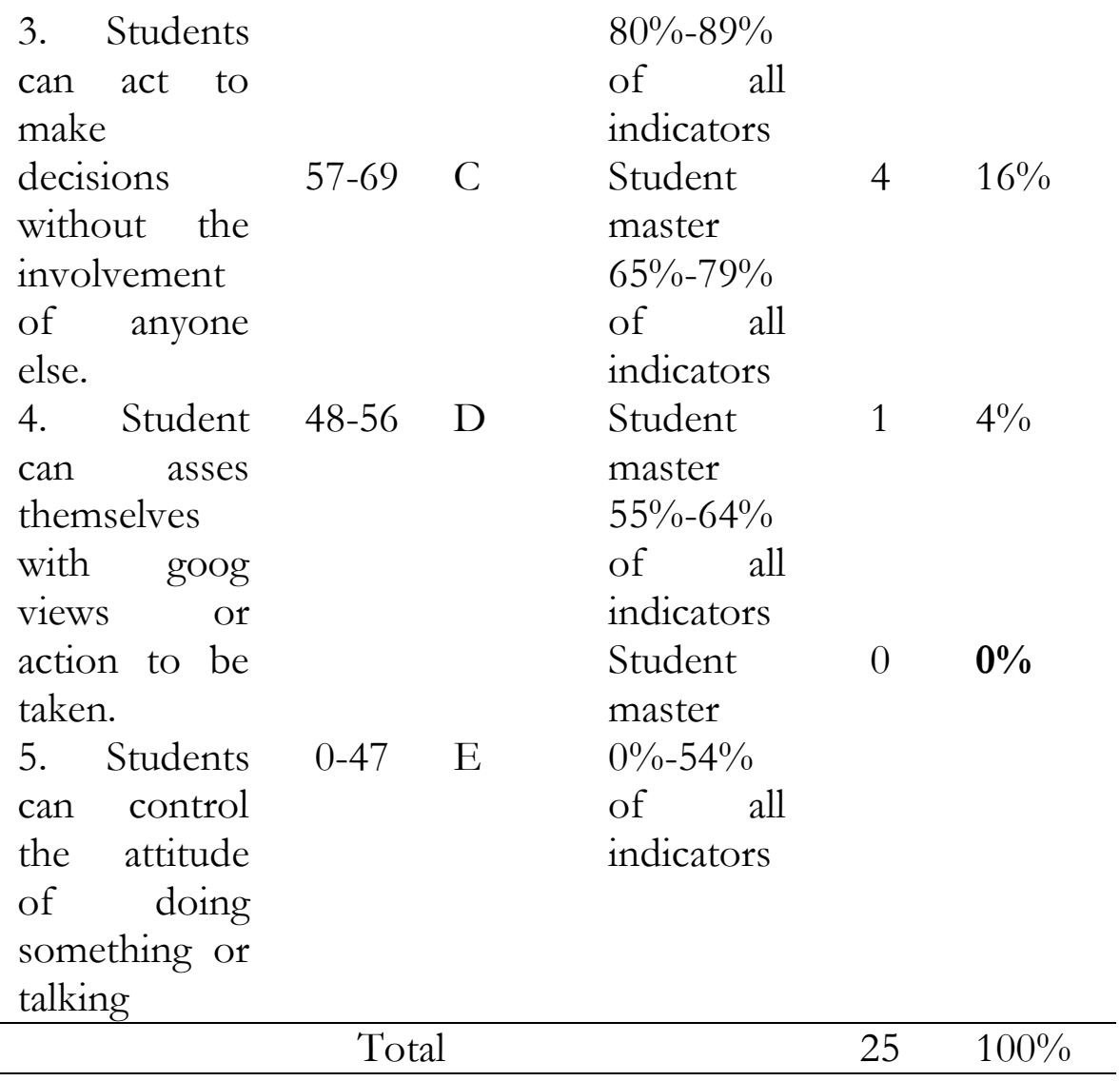

Based on the result of questionnaire above, it can be concluded that $56 \%$ students gave very good respond. It meant that, students' self-confidence included in very good category with high self confidence, and there were $24 \%$ students gave good respond included in good category with high average selfconfidence. $16 \%$ students gave responded poorly, with low selfconfidence. While the $4 \%$ students gave responded bed with very lowest self-confidence

The conclusion is it about $90 \%$ of student gave good respond, it means that most of the students had highly selfconfience during the teaching learning process that was being conducted. Self-confidence was the important aspect in learning. The effort and the learning achievement depend on the level of the students' self-confidence. 
Kamarudin et. al., The use of course...

High self-confidence OF THE students will have a better result of their learning than low self-confidence students. The students with high motivation in learning will have a bigger effort to reach their goal than the students with low self-confidence. It can be seen from the teaching learning process that had done by the researcher, students with very high self-confidence gave good attention and focus to the learning process, in other hand students with low self-confidence doesn't gave the same.

As stated previously, the researcher proposed a research question that was stated "Is Course Review Horray (CRH) strategy has effect toward students' self-confidence in learning vocabulary at the seventh grade students of MA NW Senyiur Keruak Lotim?" After computing the result of the data in this research, it was found that Course Review Horray has significant effect toward students' self-confidence in learning vocabulary. It showed that the mean score of experimental group was higher than control group. The mean score of experimental group was 74.24 , and the mean score of control group was 66.68 (74.24 $\geq 66.68)$. Further, the result of calculating t-test was higher than $\mathrm{t}$ table, the result of t-test was 2.865, while the result of t-table was 2.011 (2.865 $\geq 2.011)$.

The data showed that the Course Review Horray has positive effect. It help students solved their problem in vocabulary material because Course Review Horray gives the students chance to share their ideas, argument and information to another students/group, Course Review Horray also made the students socialization well. Based on the teaching and learning activities that have done by the researcher, it could be stated that students enjoyed the learning because Course Review Horray was new and interesting for students.

\section{CONCLUSION AND IMPLICATION}

After completing the data analysis, and other supporting data documentation process within the research held in the field of the research, then the researcher comes into the conclusion that the different scores between experimental group and control group show that there was significant score after conducting this study. 
The experimental scores after treatment was higher than control group, so that it indicates the alternative hypothesis $(\mathrm{Ha})$ on chapter I which stated that "The Effect of Course Review Horray toward students' self-confidence in learning vocabulary at MA NW Senyiur Keruak Lotim "was effective and accepted. Based on the result, in this study the number of score for ttest $(2,865)>$ ttable $(2,011)$. The alternative hypothesis $(\mathrm{Ha})$ is effective and accepted and of course the null hypothesis (Ho) is not effective and rejected. Through the result, the researcher can be concluded that Course Review Horray Strategy can improve students' self confidence in learning vocabulary. It was showed by the questionnaire of students percentage is $56 \%$ the students get qualification $\mathrm{A}$ as criteria Student master $90 \%-100 \%$ of all indicators, $24 \%$ students get qualification as B master $80 \%-89 \%$ of all indicators, $16 \%$ students get qualification as C master $65 \%-79 \%$ of all indicators, $4 \%$ students get qualification as D master 55\%-64\%, and $0 \%$ students get qualification as $\mathrm{E}$ master $0 \%-54 \%$ of all indicators. So, based on the result above, the students get qualification $\mathrm{A}$ is higher than all qualification; it means that it is very confidence on their self.

Furthermore, it is highly suggested that the researcher should give some suggestion related to the finding of the study. The researcher expects that the research will be useful for English teachers, the students and the next researcher. For the teacher: The teacher should be more creative using media or strategy that the students do not feel bored in the class. For the students: The students were more seriously in discussion and obedient to teacher in learning process especially in English learning. For the next researcher: the researcher hopes that the result of this study can be useful for the next researcher who are interested in English and for who wants to conduct further research about the use of Course Review Horray Strategy.

\section{REFERENCES}

Astuti, D. (2011). The effectiveness of invented dialogue toward students' speaking skill. Thesis.Unpublished: IkipMataram. 
Kamarudin et. al., The use of course...

Brown, H. D. (2003). Language assesment principles and classroom practice. California: Longman.

Fadli, S. (2009). The use of picture as media in teaching english vocabulary.Thesis.Unpublished: IkipMataram.

Hamid, S. (2014). Metode edu tainment. Jogjakarta: Diva Press

Kamil, M. L., \& Elfrida, H. H. (2005). Teaching \& learning vocabulary bringing research to practice. New Jersey: Lawrence Erlbaum Associates, Publisher.

Kothari, (2004). Research methodology. New age international publisher: New Delhi.

Lauster, P. (1992). Tes Keperibadian.Penerejemah. D. H. Gulo, ANS Sungguh Bersaudara. Jakarta.

Madsen, S. H. (1983). Techineques in testing. New York: Oxford University Press.

Maryanti, I. (2009). The effectiveness of puzzle word in teaching english vocabulary.Thesis.Unpublished: IKIP Mataram.

McCarten, J. (2007). Teaching vocabulary: Lessons from the corpus: Lessons from the classroom. USA: Cambridge University Press.

Miller, Stave, 2005. Experimental Design and Statistic. Second Editation. London And New York: Routledge.

Oktaviani, R. (2010). The effectiveness of puzzle word in teaching english vocabulary. Thesis.Unpublished: IkipMataram.

Rahmani, S. (2015). The effectiveness of using total physical response method to belp the students in learning english vocabulary.Thesis.Unpublished: IkipMataram.

Sarastika, P. (2014). Stop minder dan grogi. Yogyakarta: Araska.

Thornburry, S. (2002). How to teach vocabulary. England: Pearson Education Limited. 